\title{
SELECTED PROBLEMS OF THE ORGANIZATION OF COMMUNICATION INFORMATION SYSTEM IN THE TERRITORIAL DEFENCE FORCES
}

\author{
Józef JANCZAK ${ }^{1 *}$, Maciej MARCZYK ${ }^{2}$ \\ ${ }^{1}$ Faculty of Management and Command, War Studies University (WZiD ASzWoj.); j.janczak@akademia.mil.pl, \\ ORCID: 0000-0002-4453-0893 \\ ${ }^{2}$ Faculty of Military Studies, War Studies University (WW ASzWoj.); m.marczyk@akademia.mil.pl, \\ ORCID: 0000-0002-7991-8126 \\ * Correspondence author
}

Purpose: The main problem matter subject to intellectualization is the quest for an answer to the following question: How to organize the communication and information system of the territorial defence forces, taking into consideration the operational and environmental factors, so that it provides for cooperation of the forces in the framework of combined operations on the present and the future battlefield, as well as for the support of the non-military system (in emergency situations) to meet the requirements of the command bodies in accordance with the realized military and non-military mission?

Design/methodology/approach: The paper presents the results of research conducted in the framework of a statutory research task assigned by the Management and Command Faculty No. II.3.21 of year 2017 concerning the determination of the role, tasks and rules pertaining to the organization of communication in the territorial defence forces, these being an important element of the defence system of Poland.

Findings: The analysis of the available subject literature reveals that the structure of the TDF communication and information system does not differ from the solutions applied in the PAF as a whole. The authors believe that making use of the technique of augmented reality will support the building of situational awareness among soldiers.

Originality/value: The search for the directions of change in the equipment of territorial defence forces and organizing communication and IT has shown that some ICT companies have announced that they are going to equip the territorial defence subunits with mobile applications through private donation. When this comes about, the result will allow for better training and enable a more detailed picture of the assigned task, hence, the effectiveness of the new military formation will increase.

Keywords: national security, territorial defence, communication information system.

Category of the paper: literature review, general review. 


\section{Introduction}

In many European countries the attempt is being made to enhance capabilities of their armed forces at least cost. In inter war and post-war Poland, this was achieved through creating territorial defence forces and using these an integral part of operational forces. As a result of a reform of the PAF in years 2008-2011, part of the operational forces potential was shelved, alongside with the territorial defence forces. In 2017, a new concept of the territorial defence forces organization was introduced, the process was accompanied by a number of problems to be tackled concerning their role, place, and mission in the defence system of the Republic of Poland. It was decided that the need for command and control, as well as the organization of the communication information system in the territorial defence forces was a vital issue.

\section{Factors having influence on the organization of communication information system in the territorial defence forces}

The units of territorial defence forces are not compartmentalized to the category of combat readiness. They function at the time of peace and are supplemented with soldiers of the territorial military service (TMS). Depending on the compartmentalization to a given set, they have a certain time allotted for mobilization. The time to attain readiness to start operations in the permanent areas of responsibility stems from their operational earmarking. Territorial defence forces (TDF) run tactical operations in the land operational environment that are of common, constant and non-linear character. It is assumed that the TDF units, due to the specificity and the scope of activities and cooperation, should possess properly organized command and control, communication, as well as combat and logistic support. Their needs exact the necessity of implementing innovative solutions in the aforementioned fields.

The terrain and weather conditions in our country are of a very diverse character. Presently, in theory as well as in practice, some characteristic terrain conditions for conducting military operations have been recognized. The specific environment conditions of combat on the territory of Poland include: forests and forest-lake terrains, mountainous terrains, build-up areas, seaside, water obstacles. Whereas, the specific weather conditions of combat entail: winter conditions and conditions of limited visibility.

The operational factors shaping the activity of the TDF units encompass the following: reconnaissance, combat support, manoeuvre and fire. The activities are organized and performed directly by the units of TDF, supported quantifiably by the local environment.

It is assumed that the tactical activities of the detachments and sub-subunits of TDF will be realized basically in stable areas of responsibility as regular, irregular, and unconventional 
operations. Particular attention is paid to the organization of cooperation during the conduct of operations with operational and support units, as well as with the non-military system. There is a postulate to realize these in accordance with the plan of employing the Polish Armed Forces, as well as with the normative documents concerning the problem of command and control.

The command and control of the territorial defence forces entails the overall activity of the command bodies in the scope of planning, organization, preparation and maintenance of combat readiness of the means and measures of the territorial defence forces so as to realize mission demand in accordance with earmarking and in cooperation with the operational and support forces, as well as with the non-military system at all states of state defence readiness (the time of peace, crisis and war).

For efficient command in times of operations, the system of command and control has an important role to play. Here, the indispensable element of an effective ICT system provides for the circulation of information for the needs of the command and the management of combat measures. It must enable meeting requirements outlined by the rule of command and control adopted at the tactical level such as: the unity of command and control; continuity of command and control; integration of command and control; decentralization of command and control; common trust and understanding between the commander and the staff, as well as with subordinates and superiors.

\section{Mission and organizational structure of the command support subunits of the territorial defence units}

The study of the available subject literature leads to the thesis that the change of the organizational structure of the subunits supporting the command and control of TDF can be enforced in the future by technological progress and the scope of operations (which is changing in the period of time under discussion). Research conducted during military training organized by the Ministry of Defence and the Military Faculty of the War Studies University, as well as training carried out with the use of the deployed cells of TDF (WISŁA, ANAKONDA) showed that changes in the TDF command support subunits will be necessary first of all due to the application of state-of-the-art technological solutions, as well as the computerization of the information processes in the PAF, not to mention future challenges.

It is impossible to enumerate all factors having influence on the process connected with the determination of the direction of changes, however, the basic factor determining the shape of the structure of TDF command support subunits is the type of tasks that should be realized by this type of armed and organized body. Furthermore, the organizational-functional structures of the TDF command support subunits should evolve so that their elements should be independent in order to meet the need for the completion of new tasks that are first of all connected with the support of combined operations (cooperation with other NATO armies). 
They should include means and measures of all types of communication, including satellite and elements of military field mail (MFM), all supported by way of combat and logistic elements.

The TDF's command and control system should provide for the vitality of the objects and means of command and control, as well as the ability to cooperate (synchronize) and coordinate (Huzarski, 2001, p. 192) ${ }^{1}$ the courses of action with other types of the armed forces or with the components of the armed forces of the allied states and the administration authorities of the host-country. It should also assure the capability to react and adjust to the needs of the changing organization of command and control process depending on the type of the run operations.

The analysis of an organizational structure shows that the TDF command support subunits should act as independent subunits or modules ready to participate in any operations inside as well as outside the country. Their basic mission will be to organize and secure communication for the command and control bodies and to utilize the ICT system in all types of operations realized by the territorial defence forces.

Analysis of the subject literature reveals that units responsible for the organization and assurance of conditions for swift and constant command and control are present in the structures of brigades and battalions of the territorial defence. On the territorial defence brigade (TDB) level there is a command and support company (with a communication platoon), and on the level of territorial defence battalion there is a command and control company with a command and control platoon.

The TDB command and support company is an independent subunit which realizes support tasks for the need of the command and the brigade subunits (Figure 1).

The intention of the command and support company is to provide for efficiency and continuity of the $\mathrm{C} 2$ (Command and Control) system, as well as that of the brigade communication information system in all conditions of task performance; the development and support of command post (CP) operation or/and ad hoc command-observation points (C-O P); connection of brigade command post and control points to the ICT system of the operational/land forces. To attain these goals, it is planned to use the communication shelter of the MPCŁU Storczyk system.

The basic tasks of the command and support company of TDB include preparing and manning command post work places, providing their defence and protection, as well as assuring the flow of information between the command bodies and superior, co-equal or subordinate entities. The TDB command and support company should enable efficient command post activity during any and all operations. The communication platoon is the main command subunit (Figure 1) in the TDB command and support company.

\footnotetext{
${ }^{1}$ Cooperation is an agreed help of autonomic participants so as to attain a common goal, synchronization is coordination in time, coordination is the totality of planning-organizational undertakings realized in the process of preparing and conducting operations aiming at the creation of conditions for synchronized in time and space completion of tasks by all types of forces and using their varied potentials and combat possibilities [translator's note].
} 


\section{Command and support company of TDB}

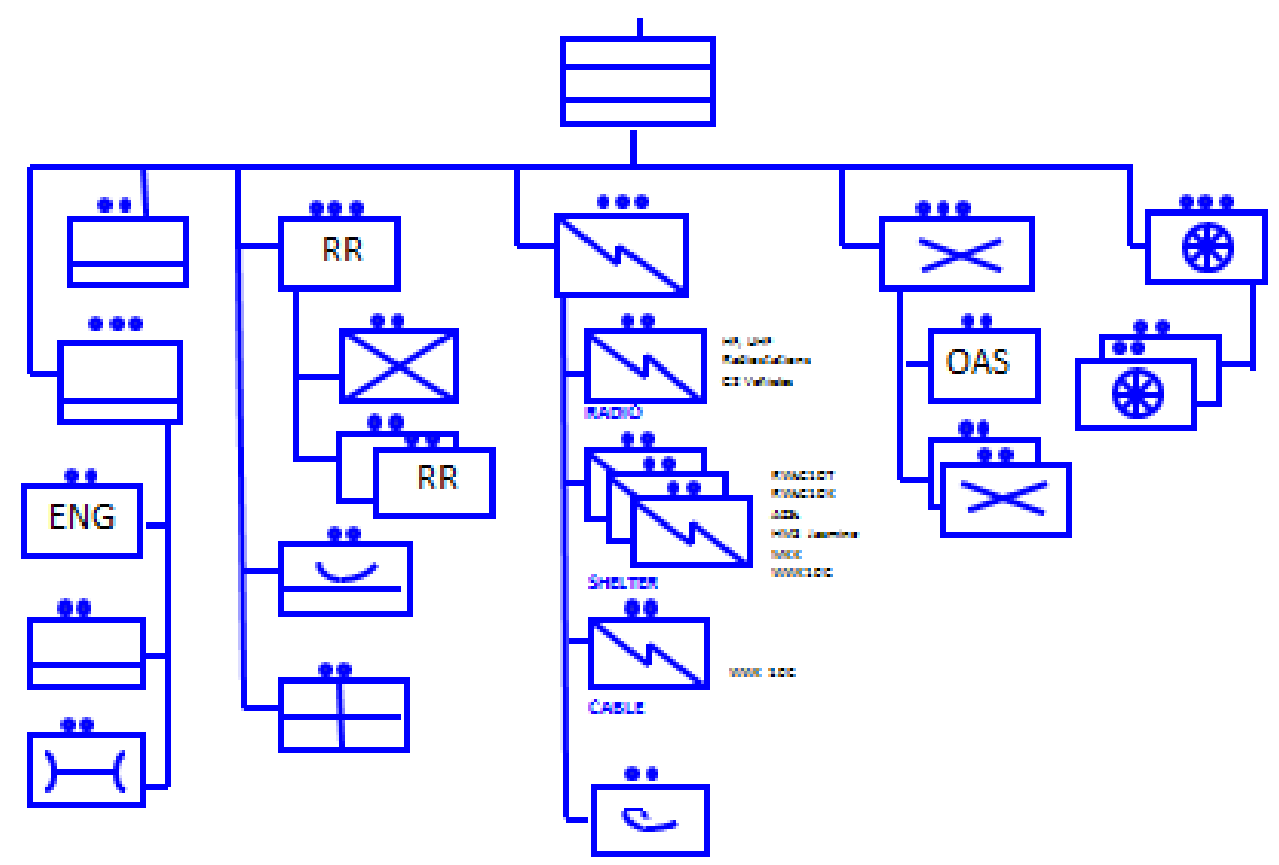

Figure 1. Organizational structure of the TDB command and support company by M. Marczyk. Based on: „Organizacja systemu łączności w wojskach obrony terytorialnej” by J. Janczak, M. Marczyk. Copyright 2018 by ASzWoj Warszawa.

The command company of the territorial defence battalion $(\mathrm{TDb})$ is an independent subunit which realizes the support tasks for the need of the command and the battalion subunits.

The basic tasks of the TDb command company include preparing and manning battalion command post work places, providing for their defence and protection, as well enabling the flow of information between superior, co-equal and subordinate entities. The command company of the territorial defence battalion should assure efficient battalion command post activity during operations through: command post operation and deployment; protection and defence, camouflage; provision of specialists, processing and storing of classified information. In the territorial defence battalion, the main subunit of command support in the command company is the communication platoon (Figure 2). 


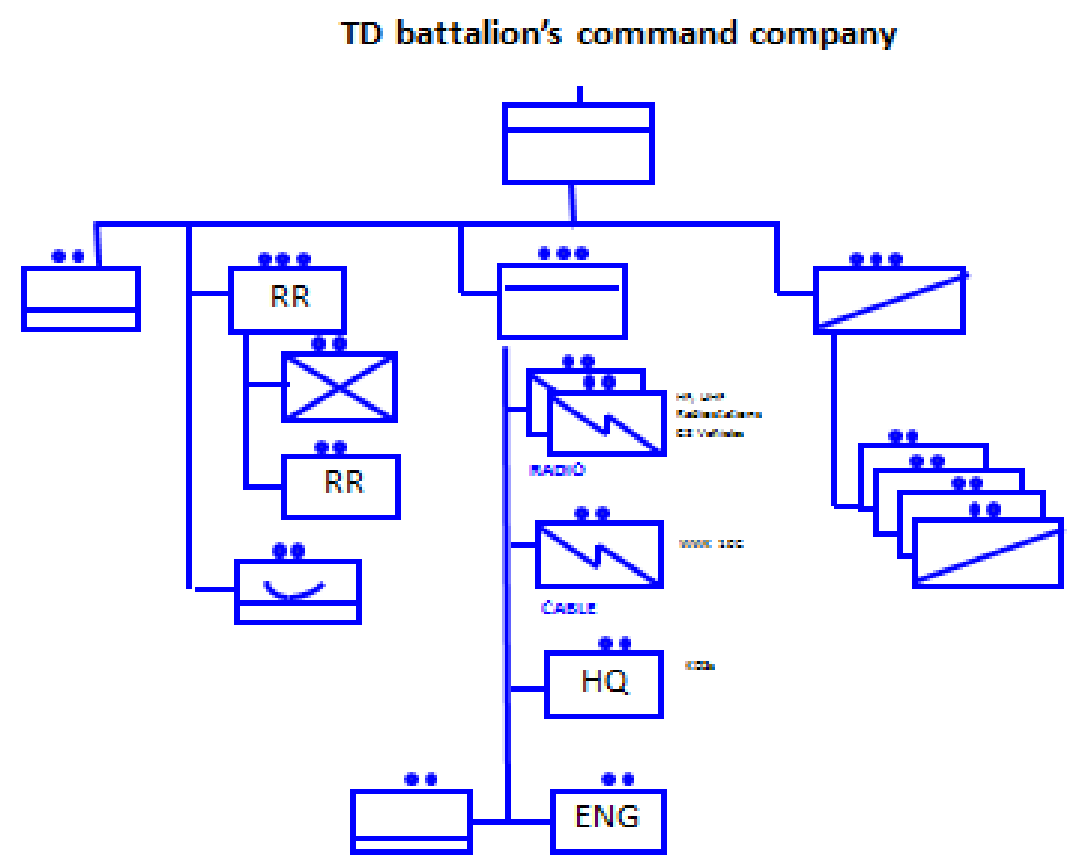

Figure 2. TD battalion command company (variant) by M. Marczyk. Based on: „Organizacja systemu łączności w wojskach obrony terytorialnej” by J. Janczak, M. Marczyk. Copyright 2018 by ASzWoj Warszawa.

An important component of the TDF command system, indeed, the basis for the functioning of the tactical level network, are the technical means of command and control (ICT means). These perform two basic functions (Janczak, Daniluk, 2003, p. 5): transferring information between the elements of the command and control system (functional people or the functional cells); supporting information processing in the command and control process.

The following division according to measures has been adopted (Frączek, 2009, p. 93):

1. ICT devices:

a) teletransmission devices:

- radiostations (radiotelephones),

- satellite terminals - used on ad hoc basis,

- cables,

b) switching devices,

c) end devices,

d) special devices (encryption devices).

2. Groups of ICT devices:

a) command vehicles,

b) command-staff vehicles,

c) mobile workplaces. 
Accumulating communication and IT measures in one subunit, as well as equipping it with automated command and control systems enables multidimensional preparation of the subunit for the realization of tasks related to the development of a communication network for the benefit of an assigned (depending on the type of operation) TD unit at the tactical level. Herein, the distinction between operations and activities of particular systems of command and control (TDF command/TD brigade or TD battalion) can only be seen in operational procedure.

It is worth highlighting the problem that arises in the usage of the communication and IT devices by subunits of TD light infantry. As it stands now, TD battalion command posts do not possess sufficient numbers of basic communication and IT equipment to enable efficient organization of command networks, e.g. radiophones, cables, satellite terminals, the element of military field mail (the equipment of mail sections or field switch-multiplexers). Currently, the possessed means of communication is limited only to: vehicle-carried RF radiostations (91 pcs), KF/UHF AN PRC - 50 manpack radiostations (17 pcs) and manpack radiostations up to $01 \mathrm{~kW}(109 \mathrm{pcs})$.

\section{Structure of Territorial Defence Forces Communication Information System}

Effective territorial defence forces task-completion activity depends on the assurance of a stable system of information exchange with all elements creating the formation, and with superior and co-existing neighbours, as well as between the elements of territorial defence and forces supporting the operations of other armed forces elements.

To attain this goal, a communication information system has been organized. Its objective is to guarantee - in the time of peace as well as crisis and war-communication (in other words to send remotely messages in different form and by different means) to the soldiers as well as to the devices supporting or replacing them that, most of all, deal with the command or management of the means of combat /armament (Janczak, Wisz, 2004, p. 8).

The communication information system is also defined as organizational-technical set of means and measures of communication and IT corresponding with the needs of command and control as well as steering the means of destruction and the character of the executed operations and tasks performed by the forces (Janczak, 2004, p. 20). Whereby, it should be emphasised that the concept of 'communication information system' has a broader meaning than 'communication network' (Mazurkiewicz, 1996, p. 176)', which is commonly used as synonyms.

\footnotetext{
${ }^{2}$ Communication network - developed (deployed and working) according to a single plan on a given area group of tightly connected means and measures of communication in order to guarantee the exchange of information in the system of command and steering the combat means [translator's note].
} 
The organization of the TDF command and control system is inextricably connected with the tasks set for the communication information system. They include the organization as well as the guarantee of timely, reliable, and clandestine communication for the need of command and control of troops and steering the means of destruction, cooperation and information, warning and alarming (Janczak, 2004, p. 10; Michniak, 2005, p. 174). To be more precise it should be assumed that in TDF subunits the assigned tasks should enable:

1. In terms of command and control - giving orders at a predetermined time to the owned elements of combat order and receiving from them reports on the realization of the set tasks in all types of operations, as well as during relocation.

2. In terms of steering the means of destruction - immediate communication of command and agreed signals, as well as the co-ordinates of the destruction targets, and the signals for mutual identification of troops.

3. In terms of troops cooperation - permanent exchange of information between all elements of the combat order, the elements of support, the neighbours and administration in the region of operations, as well as providing and receiving data on meteorological situation.

4. In terms of informing (warning and alarming) - immediate communication of signals about threats from the air (means of aerial enemy attack), the sea, the threat of the weapons of mass destruction or contamination as a result of purposeful destruction of the infrastructure in the region of operations (e.g. through the release of toxic industrial substances).

It is worth emphasising that it is necessary for each communication information system to meet the requirements determined for all organization levels of command and control. Herein, as stated by Michniak (2002, 2005), Janczak (2004), Mazurkiewicz (1996) and Frączek (2009), the following requirements must be met:

a) Operational-tactical (actual task-related activity) - timely exchange of information, accuracy of the exchanged information, as well as the secretiveness of information exchange.

b) Technical-exploitative (effective utilization of the organization and structure of the communication information system, reflecting the efficiency and the functioning of the communication information system, together with all its elements):

- operational readiness,

- throughput,

- stability,

- mobility,

- security. 
According to the subject literature (Michniak, 2002, p. 76), there are three elements that make-up an effective communication information system:

1. Subsystem of management - this consists of the points of steering and management of the communication information system, its nodes, as well as the network elements to manage the communication information system.

2. Subsystem of information exchange (communication network) - owing to which the exchange of information is realized.

3. Subsystem of support - this includes the elements of support to enable effective actual communication (combat support and troop protection, logistic support and the support of communication reserve).

The division has been accepted as the basis for determining the structure of the TDF communication information system (Figure 3).

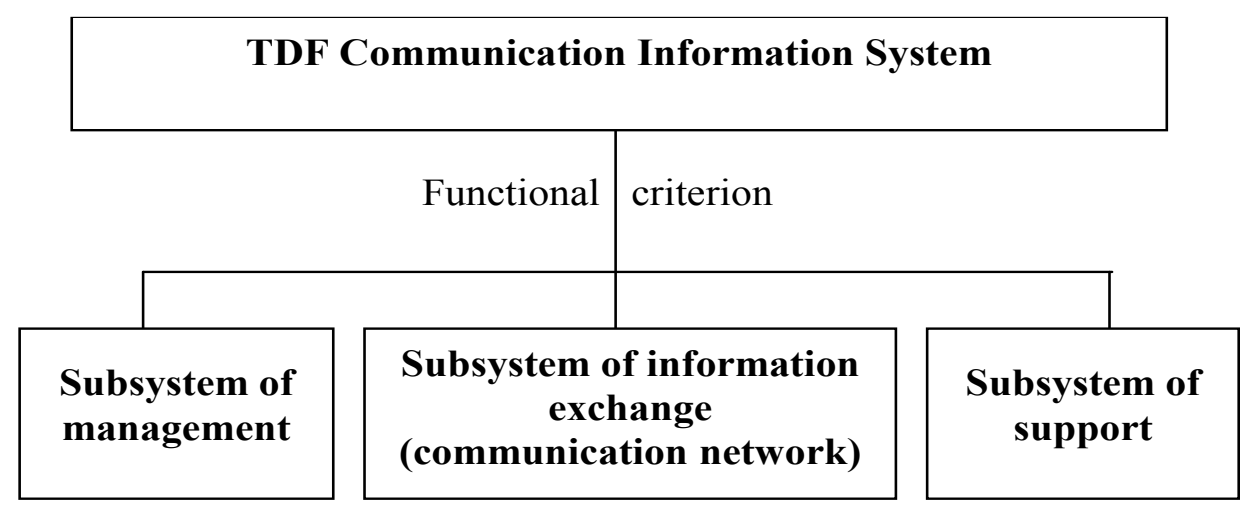

Figure 3. The structure of TDF Communication Information System by J. Janczak, M. Marczyk.

The authors believe that it is necessary to emphasise the fact that the organization of the communication information system in TDF is similar to that existing throughout the PAF. The responsibility of the functional people for the proper realization of information exchange in the system does not differ much from the procedures adopted in the land forces or special forces.

\section{Summary}

The carried out research reveals that today, many European countries are looking for costeffective ways to enhance the potential of the armed forces. In Inter-war and post-war Poland this problem was met by calling into being the forces of territorial defence as an integral part of operational forces. As a result of the reform of the PAF in years 2008-2011, part of the operational forces potential was shelved, alongside with the forces of TD. In 2015, the idea of territorial defence forces came back to life, together with a number of questions concerning their role, place and tasks, as well as the rules of usage and possibilities of equipment. 
Taking the above into consideration, it was decided to pose the following question: How, having regard to the operational and environmental factors of operations, to organize the communication and information system in the forces of territorial defence so as to provide for the cooperation of the forces in the framework of combined operations on the contemporary and the future battle field and for support of the non-military system in emergency situations, in order to meet the requirements of the command and control bodies in terms of administrating the networks of information exchange, in compliance with potential military and non-military tasks?

The considerations have demonstrated that the basic role of the territorial defence forces is to complete the combat potential of operational forces in regions (places) where their usage is operationally not grounded. This has come about because Poland does not possess enough operational forces to effectively prepare and implement strategic defensive operation across the entire length of Poland's borders and throughout the whole territory of Poland.

The adopted concept of forming a brigade in every province (in Masovian - two) allows for an optimum utilization of both human and material resources to be at disposal of the territorial administration at the time of crisis and war. All units of territorial defence formed in years 2017-2019 are to be, in organizational-conceptual terms, units of light infantry (brigades, battalions, companies, platoons, sections) armed and equipped properly in order to fulfil their operative rolls.

To accomplish its mandate, TD forces consist of territorial command and control entities, the troops of territorial defence, attached militarized units and related operatives. The bodies of command and control of the territorial defence forces are elements of the armed forces system of command and control and are composed of functional people and the separated organizational cells of the TDF command, the command of brigades and battalions, provincial military staffs, military draft offices, and even garrison offices.

The communication and information system of the territorial defence forces run tactical operations in the land operational environment, which are of common, constant, and non-linear character. The factors shaping the functioning of the TDF units include: reconnaissance, combat support, manoeuvre, and fire. The activities are organized and performed directly by units of TDF with land forces support.

For an effective command at the time of TDF operations, the system of command and control must perform the vital task of enabling the free flow of information from superior, subordinate and co-existing entities. It must enable meeting the requirements set by the command and control rules as adopted at the tactical level. These include: the unity of command and control, continuity of command and control, integration of command and control, decentralization of command and control, common trust and understanding between the commander and his staff and subordinates, as well as superiors. Furthermore, all TDF activities must be effective no matter the place or season. 
The subunits supporting the command and control, as well as communication of the TDF will be affected by technological advancement and changes in the scope of assigned tasks. The present module organizational structure of the company of command and support of the territorial defence forces brigade level should head towards the independence of their elements so as to meet the needs to realize new tasks that are, first of all, connected with the support of combined operations. The company supporting the process of command and control (regardless of the name) should include means and measures of all types of communication, i.e. satellite means and the elements of modern WPP, all supported by elements of combat and logistic support. It should be noted that the means of individual and tactical communication are presently indispensable, without it, any operation is hardly possible.

The TDF command and control system is inextricably connected with the tasks set for the communication and information system. These entail the organization and assurance of timely, accurate and secretive communication for the needs of troop command and the steering of combat or aid to civil power.

The analysis of the available subject literature reveals that the structure of the TDF communication and information system does not differ from the solutions applied in the PAF as a whole, including:

1. Subsystem of management - which entails the points of management and administration of the communication and information system, its nodes, in addition to the elements of networks to manage the system of communication and information.

2. Subsystem of information exchange (communication network) - which assures the exchange of information.

3. Subsystem of support - including the elements of support (combat support and protection of troops, logistic support, and the support of reserve communication).

The division has been accepted as the basis for the determination of the structure of the communication and information system organized for the needs of the territorial defence forces.

The search for the directions of change in the equipment of territorial defence forces and organizing communication and IT has shown that some ICT companies have announced that they are going to equip the territorial defence subunits with mobile applications through private donation (\#OTrening and \#OTakcja). When this comes about, the result will allow for better training and enable a more detailed picture of the assigned task in geographic terms, hence, the effectiveness of the new military formation will increase.

The first application was assigned the name \#OTrening and according to the assumptions, it will be used to carry out single-person or group exercises pertaining to the tasks of TDF. It will support the users in training and in learning the rules of technical system operation (e.g. arms) and in the realization of medical support tasks. Moreover, the application will allow to simulate the real world, thus it will be used to acquire knowledge and abilities used in the framework of tasks set for the territorial defence forces. The matters incorporated therein include: aiding in the resolution of natural disasters, range and training safety, reconnaissance, 
observation of objects of critical infrastructure, organizing the conduct of medical support, etc. In order to motivate users to broaden their knowledge, an avatar with the individual user's attributes will be created.

The second mobile application \#OTakcja will support the soldiers of territorial defence forces in the scope of running reconnaissance operations and the realization of typical military tasks and those in the area of crisis management. \#OTakcja provides a set of network-centric tools for building situational awareness on the battlefield or field of operations, therefore, enabling the monitoring of troop location, force levels and unit effectiveness. It also enables the transmission of data.

The authors believe that making use of the technique of augmented reality will support the building of situational awareness among soldiers. The application will also allow users to carry out hidden map, satellite and air-photo reconnaissance, including information on disaster situations and war-gaming. Moreover, the software is to provide advanced tools of terrain assessment, taking into consideration topographical, satellite and altitude data to determine basic time parameters for tasks realization.

In addition, it has been noticed that there are some promises to make mobile systems available on generally accessible devices (smartphones, tables) that will support the units of territorial defence in the course of mission realization. Certain entrepreneurs state that they are going to offer hand-held, electronic devices for 'first aid' and tactical information. The system is intended to equip the soldier and command units at the lowest levels by being a handy kit item allotted to individual soldiers and to the TDF commander at lower tactical levels. It should be emphasised that the software purchased by the forces of territorial defence are to be fully functional with the tools used by other services (the Police, Board Guard, the State Fire Service), as doing so enables a more effective exchange of information in joint operations at the time of crisis.

The WB group has also presented an offer of a communication information system that, according to the declaration of the producer, enables the possibility of communication both within the territorial defence units, as well as in the course of cooperation with other operational forces. The proposal for the territorial defence forces entails, among other notions, manpack radio stations Fastnet RRC 9211 and RRC 9311 which are basic means of communication in the PAF at higher levels of command. In the framework of the proposal for the newly formed types of armed forces they are to ensure communication between the operational units and the subunits of territorial defence forces.

As to the individual territorial units, the following communication devices are offered: type 3501, 35010 as well as software type 3509. The first two systems would be used at section and platoon level, while bigger subunits (companies, and platoons) would receive under the WB Group offer, fully programmable radio stations 3509 which belong to the 350x family. 
Radio station type 3509 is equipped with software in the shape of a wave form that allows to build a network of IP data exchange via wireless technology. It also has build-in transmission protection $-\mathrm{C}=\mathrm{OMSEC}$, NETSEC, TRANSEC that will protect the transferred data against their interception by the enemy.

A transportable set is offered for each of the three radio stations. In case of a radio station type 3509, it consists of an adapter that allows connection to IP networks, as well as an amplifier with $50 \mathrm{~W}$ power. The WB Group, as its representative claims, is able to provide the newly formed territorial defence units with a full spectrum of communication information systems based on the solutions already used in other operational forces.

\section{References}

1. Aplikacje mobilne wespra OT, Available online http://www.cyberdefence24.pl/, 19.07.2019.

2. Banaszek, T. (2013). Obrona Terytorialna Kraju w województwie kieleckim (1963-1975). Organizacja i działalność. Przegląd Historyczno-Wojskowy, 2.

3. Frączek, M. (2009). Bezpieczeństwo wymiany informacji w sieci teleinformatycznej brygady zmechanizowanej. Warszawa: AON.

4. Huzarski, M. (2001). Taktyka ogólna wojsk lądowych. Warszawa: AON.

5. Jaka obrona terytorialna potrzebna jest Polsce, Available online http://www.security direct.pl/, 20.07.2019.

6. Jakubczak, R. (2002) Wojska Obrony Terytorialnej. Bellona.

7. Jakubczak, R. (2015). Wspótczesne wojska obrony terytorialnej. Bellona.

8. Jakubczak, R., Marczak, J. (1998). Obrona Terytorialna Polski na progu XXI wieku. Bellona.

9. Janczak, J. Marczyk, M. (2018). Organizacja systemu łączności w wojskach obrony terytorialnej. Warszawa: ASzWoj.

10. Janczak, J., Daniluk, P. (2003). Środki dowodzenia. Warszawa: AON.

11. Janczak, J., Wisz, A. (2004). System łączności brygady. Warszawa: AON.

12. Kajetanowicz, J. (2008). Wojska Lądowe Obrony Terytorialnej Kraju w systemie bezpieczeństwa wewnętrznego Polski w latach 1959-1989. Zeszyty Naukowe AON, 4.

13. Kajetanowicz, J. (2013). Wojska Obrony Terytorialnej Kraju w systemie bezpieczeństwa Polski w latach 1959-1989. Poligon, 2(37).

14. Mazurkiewicz, J. (1996). Leksykon łączności wojskowej. Warszawa: AON.

15. Michniak, J. (2002). Kierowanie mobilnymi systemami łączności wojsk ladowych. Cz. I: Główne problemy. Warszawa: AON.

16. Michniak, J. (2005). Dowodzenie i łączność. Warszawa: AON. 
17. Polska łączność dla obrony terytorialnej, Available online http://www.defence24.pl/, 20.07.2019.

18. Rozporządzenie MON W sprawie powotywania do terytorialnej służby wojskowej i sposobu jej petnienia, z dnia 24 lutego $2017 \mathrm{r}$.

19. Sily zbrojne RP/OT, Available online http://militarium.net/category/19.07.20292019.

20. Ustawa o zmianie ustawy o powszechnym obowiazku obrony Rzeczypospolitej Polskiej oraz niektórych innych ustaw, z dnia 16 listopada 2016 r.

21. WKU Białystok, Available online http://bialystok.wku.wp.mil.pl/, 20.07.2019. 